\title{
Differentiation of Streptococcus sanguis and $S$. mitior by whole-cell rhamnose content and possession of arginine dihydrolase
}

\author{
T. PRICE, G. L. FRENCH*, H. TALSANIA and I. PHILLIPSt
}

Department of Microbiology, St Thomas' Hospital, London SE1 TEH

\begin{abstract}
Summary. Whole-cell rhamnose concentrations were measured in 48 strains of streptococci resembling Streptococcus sanguis and $S$. mitior. Physiological characteristics were tested by the API-20/Strep system, and it was found that "typical" $S$. sanguis (arginine positive, aesculin positive) contained significant amounts of rhamnose, while "typical" $S$. mitior (arginine negative, aesculin negative) contained very low or undetectable amounts of rhamnose. Both groups contained dextran-positive and dextran-negative strains. Organisms that were more difficult to speciate (those giving positive results in the arginine or the aesculin test, but not in both) could also be divided into a rhamnose-positive and a rhamnose-negative group; with one exception, all of the rhamnose-positive strains gave a positive result with arginine in the API-20/ Strep test.

There were several discrepancies between the results of conventional tests for arginine and aesculin hydrolysis and those of the corresponding API test. The results of conventional tests for arginine hydrolysis did not correlate closely with rhamnose content, and conventional tests for aesculin hydrolysis were less sensitive than API tests. With the API-20/Strep system, $S$. sanguis can almost always be distinguished from $S$. mitior by its ability to hydrolyse arginine.
\end{abstract}

\section{Introduction}

White and Niven (1946) isolated a group of $\alpha$ haemolytic streptococci from cases of endocarditis and named them Streptococcus s.b.e. These organisms produced dextran from sucrose (Niven et al., 1946) and are now known as $S$. sanguis. There is general agreement on the identification of typical $S$. sanguis strains, which are usually $\alpha$-haemolytic, hydrolyse arginine and aesculin, ferment lactose, sucrose, trehalose and inulin, produce hydrogen peroxide, form dextran from sucrose, and grow in the presence of $40 \%$ bile. However, many authors have broadened the species definition to include in S. sanguis strains that are dextran negative (Colman and Williams, 1972; Facklam, 1977), arginine negative (Facklam, 1977), or aesculin negative (Colman and Williams, 1972) (table I).

Washburn et al. (1946) described two type anti-

Received: 4 Jan. 1985; revised version accepted 8 May 1985. *Present address: Department of Microbiology, The Chinese University of Hong Kong, Shatin, New Territories, Hong Kong. †Correspondence and offprint requests should be sent to Professor I. Phillips. gens of $S$. sanguis: I (represented by strain ATCC 10556/NCTC 7863) and II (represented by strain ATCC 10557/NCTC 7864). A few strains carried both antigens, and were designated I/II (represented by strain ATCC 10558/NCTC 7865). Members of serotypes I and I/II were found to belong to Lancefield-group $\mathrm{H}$ but $S$. sanguis type II did not (Hare, 1935; Porterfield, 1950). Porterfield found that type-II strains were physiologically distinct and this has been confirmed more recently by Hamada et al. (1980).

Streptococci differ in the amounts of glucose, galactose, rhamnose and other sugars in their cellwalls (Cummins and Harris, 1956; Roberts and Stewart, 1961; Slade and Slamp, 1962; Colman and Williams, 1965). Colman and Williams (1965) noted that amongst $\alpha$-haemolytic streptococci resembling $S$. sanguis, strains of Lancefield-group $\mathrm{H}$ contained rhamnose but not ribitol, whereas those not of this group contained little or no rhamnose and large amounts of ribitol. This was confirmed by Rosan (1976), and Colman and Williams (1972) later called these rhamnose-deficient strains $S$. mitior. Rosan and Applebaum (1979) believe that the group-H antigen of $S$. sanguis is a glycerol teichoic acid, and 
Table I. Physiological reactions of organisms resembling Streptococcus sanguis reported in earlier publications

\begin{tabular}{|c|c|c|c|c|c|c|c|}
\hline \multirow[b]{2}{*}{ Test } & \multicolumn{7}{|c|}{$\begin{array}{l}\text { Percentage of strains giving a positive } \\
\text { reaction in the stated test in }\end{array}$} \\
\hline & $1^{1^{*}}$ & $\begin{array}{c}2 \\
(25)\end{array}$ & $\begin{array}{c}3 \\
(35)\end{array}$ & $\begin{array}{c}4 \\
(29)\end{array}$ & $\begin{array}{c}5 \\
(81)\end{array}$ & $\begin{array}{c}6 \\
(202)\end{array}$ & $\begin{array}{c}7 \\
(97)\end{array}$ \\
\hline $\begin{array}{l}\text { Hydrolysis of: } \\
\text { arginine } \\
\text { aesculin }\end{array}$ & $\begin{array}{r}100 \\
86\end{array}$ & $\begin{array}{r}100 \\
72\end{array}$ & $\begin{array}{l}91 \\
57\end{array}$ & $\begin{array}{r}90 \\
100\end{array}$ & $\begin{array}{l}91 \\
84\end{array}$ & $\begin{array}{l}64 \\
77\end{array}$ & $\begin{array}{l}99 \\
91\end{array}$ \\
\hline Production of dextran & 95 & 96 & 57 & 93 & 72 & 72 & 100 \\
\hline
\end{tabular}

* $1=$ White and Niven (1946); 2 = Carlsson (1968) (group IB); $3=$ Colman and Williams (1972); $4=$ Hardie and Bowden (1976) (S. sanguis I); $5=$ Parker and Ball (1976); 6 = Facklam 1977 (S. sanguis I); 7 = Hamada et al. (1980) (S. sanguis serotypes I, III, IV, UT).

$\dagger$ Number of strains examined.

that this is replaced in $S$. mitior by a ribitol teichoic acid.

Transformation and DNA-homology studies have confirmed that $S$. mitior and $S$. sanguis are genetically distinct (Colman, 1969; Coykendall and Specht, 1975; Coykendall and Munzenmaier, 1978). The name $S$. mitior was used by Schotmüller (1903) and pre-dates the description of similar organisms as $S$. mitis by Andrewes and Horder (1906). The names $S$. sanguis II, $S$. mitis and $S$. mitior tend to be used interchangeably in the literature.

Organisms resembling $S$. mitior of Colman and Williams (1972) are typically arginine and aesculin negative, form hydrogen peroxide, ferment sucrose and lactose but rarely mannitol, sorbitol or inulin, and are relatively bile and salt tolerant. The $S$. mitior strains of Colman and Williams (1972) were mainly dextran negative but $S$. sanguis II and $S$. mitis strains reported by other workers show considerable variations in this character (table II). Parker and Ball (1976) recognised dextran-positive and dextran-negative varieties of $S$. mitior, and Coykendall and Munzenmaier (1978) did not find dextran production to be a genetically significant characteristic. Facklam (1977) divided his aesculinnegative $S$. mitior-like strains arbitrarily into the raffinose-positive $S$. sanguis II and the raffinosenegative $S$. mitior, (table II) but Coykendall and Munzenmaier (1978) could find no genetic justification for this.

Table II. Physiological reactions of organisms resembling Streptococcus mitior reported in earlier publications

\begin{tabular}{|c|c|c|c|c|c|c|c|}
\hline \multirow[b]{2}{*}{ Test } & \multicolumn{7}{|c|}{$\begin{array}{l}\text { Percentage of strains giving a positive } \\
\text { reaction in the stated test in }\end{array}$} \\
\hline & $\begin{array}{c}2^{*} \\
(15) \dagger\end{array}$ & $\begin{array}{c}3 \\
(46)\end{array}$ & $\begin{array}{c}4 \\
(10)\end{array}$ & $\begin{array}{c}5 \\
(120)\end{array}$ & $\begin{array}{l}6 \mathrm{a} \\
(231)\end{array}$ & $\begin{array}{l}6 \mathrm{~b} \\
(177)\end{array}$ & $\begin{array}{c}7 \\
(16)\end{array}$ \\
\hline $\begin{array}{l}\text { Hydrolysis of: } \\
\text { arginine } \\
\text { aesculin }\end{array}$ & $\begin{array}{l}0 \\
0\end{array}$ & $\begin{array}{l}7 \\
4\end{array}$ & $\begin{array}{l}0 \\
0\end{array}$ & $\begin{array}{l}0 \\
0\end{array}$ & $\begin{array}{l}21 \\
30\end{array}$ & $\begin{array}{l}16 \\
33\end{array}$ & $\begin{array}{l}0 \\
0\end{array}$ \\
\hline Production of dextran & 100 & 11 & 100 & 30 & 43 & 10 & 100 \\
\hline
\end{tabular}

* $2=$ Carlsson (1968) (Group IA); 3=Colman and Williams (1972) (S. mitior); $4=$ Hardie and Bowden (1976) (S. sanguis II); $5=$ Parker and Ball (1976); 6a = Facklam (1977) (S. sanguis II); 6b = Facklam (1977) (S. mitis); 7 = Hamada et al. (1980) (S. sanguis serotype II).

+ Number of strains examined. 
Because various authors allow different reactions within both $S$. sanguis and S. mitior, their differentiation in the clinical laboratory is often difficult. Parker and Ball (1976) classified as $S$. sanguis organisms that gave positive results in two or more of the three tests for arginine and aesculin hydrolysis and dextran production, whereas strains that were negative for all three tests they called $S$. mitior. These authors isolated in addition a number of dextran-negative organisms that had other reactions intermediate between those of $S$. sanguis and $S$. mitior; these they were unable to classify.

In summary, it appears that most authorities recognise typical $S$. sanguis and $S$. mitior (the latter sometimes being referred to as $S$. mitis or $S$. sanguis II), but that atypical or intermediate strains are allocated arbitrarily between these two groups. Typical $S$. sanguis is arginine and aesculin positive, belongs to Lancefield-group $\mathrm{H}$ and Washburnserotype I and has moderate to large amounts of rhamnose but no ribitol in the cell wall. Typical $S$. mitior is arginine and aesculin negative, is not of group $\mathrm{H}$, but is of serotype II, and contains ribitol but little or no rhamnose in the cell wall. The serological and chemical tests are difficult to perform, and are unlikely to be used routinely for identification in a clinical laboratory.

To determine which tests are significant for the identification of these organisms, we performed physiological characterisation tests on streptococci resembling $S$. mitior and $S$. sanguis, and measured their whole-cell rhamnose content. Rhamnose has previously been estimated only in cell walls (Colman and Williams, 1965; Rosan, 1976; Roberts et al., 1979). We measured whole-cell rhamnose, which is a simpler procedure, and we have performed characterisation tests both by conventional methods and by means of the API-20/Strep system.

\section{Materials and methods}

\section{Bacterial strains}

The origins of the 48 streptococcal strains examined are specified in tables III-V. In these we give, in addition to our own serial number, the strain designation of the laboratory from which it had been obtained, and coded information about the donor of the strain $\mathrm{JH}=\mathrm{Dr} \mathrm{J}$. M. Hardie, Department of Oral Microbiology, The London Hospital Medical College; $\mathrm{LH}=$ Department of Microbiology, The London Hospital Medical College; $\mathrm{MS}=\mathrm{Dr}$ M. S. Shafi, Department of Microbiology, Central Middlesex Hospital; $\mathrm{NC}=$ National Collection of Type Cultures, Central Public Health Laboratory; RL $=$ Streptococcus and Staphylococcus Reference Laboratory,
Central Public Health Laboratory; $\mathrm{TH}=$ Clinical isolates from Department of Microbiology, St Thomas' Hospital), and about its site of isolation ( $\mathrm{BC}=$ blood culture; $\mathrm{WS}=$ wound swab; $\mathrm{O}=$ oral; $\mathrm{CSF}=$ cerebrospinal fluid; $\mathrm{SP}=$ sputum; ?= site unknown).

\section{Characterisation tests}

Organisms were tested by the API-20/Strep system and by conventional methods. API-20/Strep (API-System S.A., France) is a commercial test kit specially designed for the identification of streptococci and consisting of a gallery of 20 physiological and enzymatic tests: for acetoin production; hydrolysis of hippurate and aesculin; fermentation of ribose, arabinose, mannitol, sorbitol, lactose, trehalose, inulin, raffinose, starch and glycogen; and for possession of the enzymes pyrrolidonylarylamidase, $\alpha$-galactosidase, $\beta$-galactosidase, $\beta$-glucuronidase, alkaline phosphatase, leucine aminopeptidase and arginine dihydrolase. The detection of the latter enzyme was taken as indicating arginine hydrolysis. The kit was used according to the manufacturer's instructions.

Conventional characterisation tests were performed according to the methods of Cowan (1974) and Waitkins et al. (1980). These included tests for: colonial morphology and haemolysis on horse-blood agar; the production of catalase and hydrogen peroxide; the hydrolysis of arginine, aesculin, starch and urea; and the production of dextran and laevan from sucrose (tested by the ethanolprecipitation method). When conventional and API results differed, the tests were repeated.

\section{Estimation of rhamnose in whole cells}

Todd-Hewitt broth $(150 \mathrm{ml})$ was inoculated from a purity plate and incubated at $37^{\circ} \mathrm{C}$ for $24 \mathrm{~h}$, or until heavy growth was visible. The broth was then centrifuged at $1500 \mathrm{~g}$ for $15 \mathrm{~min}$ and the supernate discarded. The deposit was placed in a weighed test tube and dried at $80^{\circ} \mathrm{C}$ in a BT3 heater unit (Grants Instruments, Basingstoke, Hants). The tube was reweighed and the dry weight of the deposit calculated.

A modification of the hydrolysis method described by Cummins and Harris (1956) was used: $2 \mathrm{ml}$ of $2 \mathrm{~N} \mathrm{H}_{2} \mathrm{SO}_{4}$ was added to the dried cells and heated at $100^{\circ} \mathrm{C}$ for $2 \mathrm{~h}$ in a sealed tube. The extract was neutralised with $1 \mathrm{~N} \mathrm{NaOH}$ and then centrifuged at $1500 \mathrm{~g}$ for $10 \mathrm{~min}$. The supernate was then pipetted off and its volume was recorded; it was stored at $4^{\circ} \mathrm{C}$ until required.

The hydrolysed sample was desalted with Duolite MB5113 mixed resin (BDH Chemicals Ltd) which had been converted to the acetate form (Menzies et al., 1978); this left almost all the sugar in the supernate. Thin-layer chromatography was performed according to the method of Menzies et al. (1978) on Merck 60 chromatography plates: $2.5 \mu \mathrm{l}$ of the hydrolysed sample was applied and the chromatogram developed with an ethyl acetate:pyri- 
dine : glacial acetic acid: water $(60: 30: 10: 10)$ solvent system. A p-aminobenzoic acid reagent (Menzies et al., 1978) was used to locate rhamnose on the chromatogram. Sorbose was selected as the internal marker sugar as it was not detected in any of the samples, nor found to interfere with any of the chromatographic bands.

Each series of zones produced from a sample was cut into strips and scanned in the axis of chromatographic development by reflective densitometry against an opaque matt white Formica backing. A Chromoscan 200 double-beam recording and integrating densitometer with a quartz-iodine light source, blue filter and $5 \times 0.5$ $\mathrm{mm}$ light slit, and sample holder drive in 1:1 gear ratio (Joyce-Loebl and Co. Ltd, Team Valley, Gateshead, Durham) was found to be suitable for this purpose. Peak heights were measured from the scan profile and were then corrected by applying an "internal marker" factor which compensated for variation in application volume and other variables.

The amount of rhamnose in each sample was measured in the Chromoscan and recorded as height $(\mathrm{mm})$ of the relevant peak. Seven chromatograms were run, each having four rhamnose standards. The internal marker correction factor was applied, calibration curves constructed, and the rhamnose concentration in $2.5 \mu \mathrm{l}$ of each sample calculated.

\section{Results}

\section{Cultural and biochemical tests}

All the organisms were gram-positive cocci in chains that were catalase-negative, produced hydrogen peroxide and possessed leucine aminopeptidase. All but one were $\alpha$-haemolytic on blood agar, the exception being the non-haemolytic dextrannegative $S$. sanguis strain 166 . None hydrolysed urea or hippurate. Only one (the dextran-positive $S$. sanguis strain 91) hydrolysed starch in the conventional test, though a number of others showed starch hydrolysis in the API test. None produced laevan from sucrose. All strains failed to ferment mannitol, arabinose and glycogen; only one fermented sorbitol (the "intermediate" strain 110) and all but one (no. 167, a dextran-negative $S$. sanguis) fermented lactose. No strain possessed pyrrolidonylarylamidase or $\beta$-glucuronidase, and only two possessed $\beta$-galactosidase (strain 12, a dextrannegative $S$. mitior, and no. 94 , an intermediate strain).

Table III. Characters of strains identified as Streptococcus sanguis*

\begin{tabular}{|c|c|c|c|c|c|c|c|c|c|c|c|c|c|c|c|}
\hline \multirow{2}{*}{$\begin{array}{c}\text { Serial } \\
\text { no. }\end{array}$} & \multirow{2}{*}{$\begin{array}{l}\text { Donor's } \\
\text { code }\end{array}$} & \multirow[b]{2}{*}{ Origin $\dagger$} & \multicolumn{9}{|c|}{ API-20/Strep tests $\ddagger$} & \multicolumn{3}{|c|}{$\begin{array}{c}\text { Conventional } \\
\text { tests }\end{array}$} & \multirow{2}{*}{$\begin{array}{c}\text { Percentage of } \\
\text { rhamnose in } \\
\text { whole cell }\end{array}$} \\
\hline & & & Arg & Aes & Raf & In & Tre & Rib & St & $\alpha-G$ & Pho & Arg & Aes & Dex & \\
\hline 7 & $\mathrm{R} 79 / 334$ & RL:WS & + & + & - & - & + & - & - & - & + & + & + & + & $3 \cdot 25$ \\
\hline 16 & L/Sang & $\mathrm{JH}: \mathrm{O}$ & + & + & - & + & + & - & - & - & + & - & + & + & 3.40 \\
\hline 18 & $\mathrm{BC}: 1770$ & $\mathrm{TH}: \mathrm{BC}$ & + & + & - & + & + & - & - & - & + & + & + & + & 2.05 \\
\hline 24 & $\mathrm{H} 730$ & $\mathrm{JH}: \mathrm{O}$ & + & + & - & - & + & - & - & - & + & + & + & + & $1 \cdot 76$ \\
\hline 37 & $\mathrm{BC}: 1746$ & $\mathrm{TH}: \mathrm{BC}$ & + & + & - & + & + & - & - & - & + & + & + & + & 1.75 \\
\hline 44 & NCTC7865 & $\mathrm{NC}: \mathrm{BC}$ & + & + & - & - & + & - & - & - & + & - & + & + & 1.74 \\
\hline 46 & Carlsson 903 & $\mathrm{JH}: \mathrm{O}$ & + & + & - & - & + & - & - & - & + & - & + & + & 3.61 \\
\hline 56 & M517 & $\mathrm{JH}: \mathrm{O}$ & + & + & + & + & + & - & + & + & - & + & + & + & 1.65 \\
\hline 66 & R79/3247 & RL:BC & + & + & - & + & + & - & - & - & + & + & + & + & 1.99 \\
\hline 91 & $\mathrm{BC}: 1821$ & $\mathrm{TH}: \mathrm{BC}$ & + & + & - & + & + & - & + & - & - & + & + & + & $2 \cdot 96$ \\
\hline 55 & $\mathrm{BC}: 1736$ & $\mathrm{TH}: \mathrm{BC}$ & + & + & - & + & + & - & - & - & + & - & + & - & 3.05 \\
\hline 96 & $\mathrm{~L} 24 / 80 \mathrm{BC}$ & LH:BC & + & + & - & - & + & - & - & - & - & + & - & - & $2 \cdot 22$ \\
\hline 166 & Kendall & $\mathrm{TH}: \mathrm{BC}$ & + & + & - & - & - & - & + & - & - & + & + & - & 1.41 \\
\hline 167 & M371 & $\mathrm{JH}: \mathrm{O}$ & + & + & - & - & + & - & - & + & - & + & + & - & $1 \cdot 26$ \\
\hline
\end{tabular}

* Gave a positive reaction in API-20/Strep tests for fermentation of arginine and aesculin.

$\dagger$ Donor: site of isolation (see Materials and methods).

$\ddagger$ Hydrolysis of: $\mathrm{Arg}=$ arginine, Aes = aesculin; fermentation of $\mathrm{Raf}=$ raffinose, $\mathrm{In}=$ inulin, Tre $=$ trehalose, $\mathrm{Rib}=\mathrm{ribose}, \mathrm{St}=\mathrm{starch}$; formation of: $\alpha-G=\alpha$-galactosidase, Pho $=$ alkaline phosphatase, Dex $=$ dextran; $+=$ positive reaction, $-=$ negative reaction. 


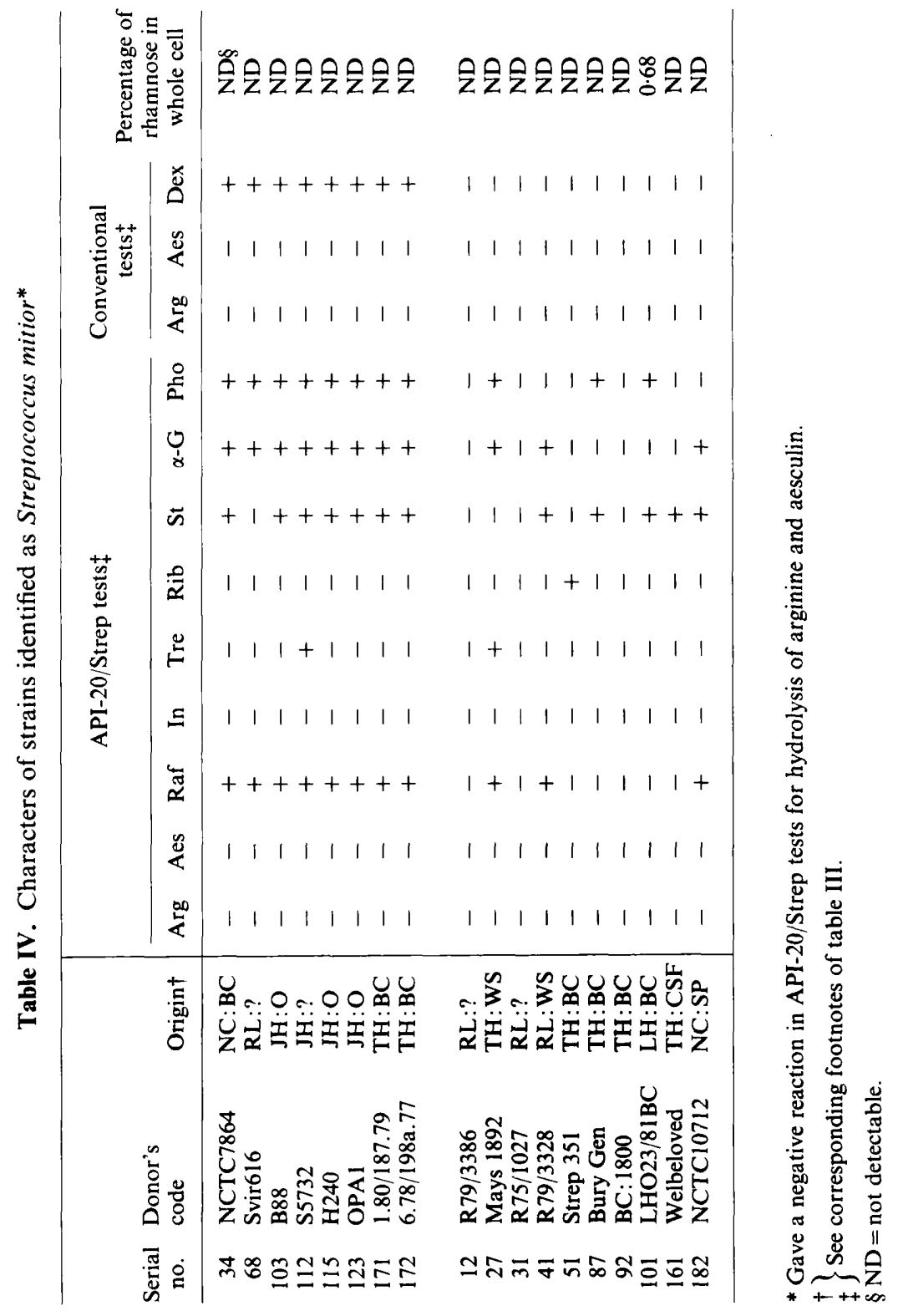




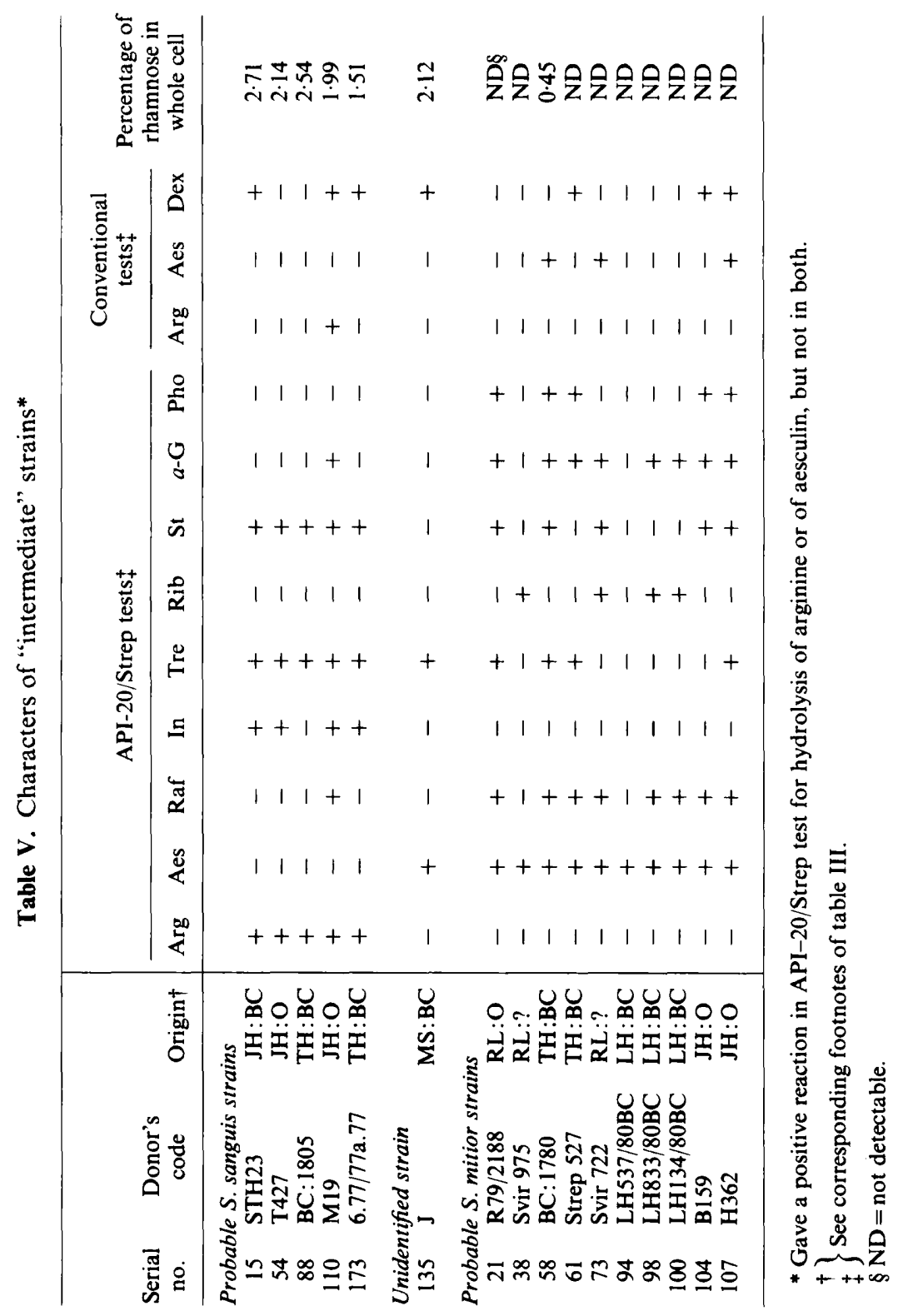


The organisms could be divided by the results of API-20/Strep into 14 strains of typical $S$. sanguis (aesculin and arginine positive), 18 strains of typical S. mitior (aesculin and arginine negative), and 16 "intermediate" strains (either aesculin or arginine positive, but not both) (tables III-V). In all three groups there were dextran-positive and dextrannegative strains. Although $S$. sanguis strains tended to be more reactive than $S$. mitior in the other API tests, none of these helped to classify the "intermediate" group.

However, eight strains that were arginine positive by API-20/Strep test were arginine negative by the conventional method. Four of these were otherwise typical $S$. sanguis strains, and included three reference strains that are said to be arginine positive by other workers (table III). The other four isolates were aesculin-negative "intermediate" strains that would have been classified as $S$. mitior had the arginine result been taken as negative (table V).

There were also nine strains that were aesculin positive by the API test but aesculin negative by the conventional method. One of these was the $S$. sanguis strain 96 (table III), but the remaining eight were "intermediate" strains (table V). If these eight strains had been regarded as aesculin negative, they would have been classified as typical $S$. mitior.

\section{Rhamnose content of whole cells}

The lowest concentration of rhamnose detectable by the examination of $2.5 \mu \mathrm{l}$ samples was $75 \mu \mathrm{g} / \mathrm{ml}$. Only one strain classified as typical $S$. mitior by the API tests yielded detectable amounts of rhamnose; that was the dextran-negative strain 101 which contained $143.3 \mu \mathrm{g} / \mathrm{ml}$, a percentage concentration of $0.68 \%$ (table IV). In contrast, typical strains of $S$. sanguis contained $385 \cdot 2-1356 \cdot 5 \mu \mathrm{g} / \mathrm{ml}$, corresponding to whole-cell rhamnose concentrations of $1 \cdot 26$ $3.61 \%$ (table III).

"Intermediate" strains showed concentrations of rhamnose varying from undetectable to $2.71 \%$ (table V). With one exception, strains that yielded $>1 \%$ of rhamnose hydrolysed arginine when tested by the API method. The exception was strain 135, a blood-culture isolate that was dextran and aesculin positive, and which contained $2 \cdot 12 \%$ rhamnose.

Thus all 19 strains that hydrolysed arginine when tested by the API method had high whole-cell concentrations of rhamnose $(1 \cdot 26-3 \cdot 61 \%)$, whereas only one of 29 strains that did not hydrolyse arginine contained a concentration of rhamnose greater than $0.68 \%$. In 26 of 29 arginine-negative strains, rhamnose was undetectable.

\section{Discussion}

The hydrolytic procedure based on that described by Cummins and Harris (1956) was found to be suitable for the production of monosaccharides from the whole streptococcal cell, and yielded results comparable with those reported for isolated cell-walls.

With the API test results, typical strains of $S$. sanguis and $S$. mitior were easily identified, and it was confirmed that all strains of $S$. mitior contained undetectable or very low levels of rhamnose, while $S$. sanguis strains contained significant amounts of this sugar. Of the 16 "intermediate" strains, six yielded significant amounts of rhamnose, and all but one of these hydrolysed arginine when tested by the API method and could be classified as $S$. sanguis. The remaining ten "intermediate" strains contained undetectable or low levels of rhamnose, and could be classified as aesculin-positive $S$. mitior. All ten strains failed to hydrolyse arginine. Both the $S$. sanguis and the $S$. mitior groups contained dextran-positive and dextran-negative strains; this character does not appear to be useful in defining the species.

There were a number of discrepancies between conventional and API results for arginine and aesculin hydrolysis. This had previously been noted for aesculin hydrolysis by Bridge and Sneath (1983). We preferred the API results for arginine hydrolysis to those obtained by the conventional method for the following reasons: (1) three $S$. sanguis reference strains were positive for arginine hydrolysis by the API test but were repeatedly negative by the conventional method; (2) there was a direct relationship between API arginine-hydrolysis and the possession of significant amounts of rhamnose by presumed $S$. sanguis strains; and (3) four aesculinnegative "intermediate" strains that would have been classified as arginine-negative $S$. mitior by conventional methods had a high rhamnose content and were better classified as API arginine-positive $S$. sanguis.

The API test for aesculin hydrolysis also gave more positive results than the conventional method. Seven "intermediate" strains that were arginine negative by both methods were aesculin positive by API but aesculin negative by conventional methods (table V). These seven strains did not contain significant amounts of rhamnose and were therefore presumed to be $S$. mitior strains. By conventional testing they would be classified as typical $S$. mitior, but by the API method they are $S$. mitior, aesculin positive. 
If it is accepted that $S$. sanguis can be aesculin negative and $S$. mitior can be aesculin positive, then, with the exception of one strain, the only physiological characteristic that can reliably distinguish between these two species is the ability of $S$. sanguis to hydrolyse arginine when tested by the API method.

Table I shows that previous workers, with the exception of Facklam (1977), have found that at least $90 \%$ of $S$. sanguis strains hydrolyse arginine. It is notable that all 42 of White and Niven's (1946) original "s.b.e." strains and 96 of the 97 S. sanguis non-serotype-II strains of Hamada et al. (1980) were arginine positive. Most strains are also reported to hydrolyse aesculin, but this property is more variable (table I).

Again, with the exception of Facklam (1977), previous workers have found that strains resembling $S$. mitior usually do not hydrolyse arginine or aesculin (table II). Colman and Williams (1972)

\section{REFERENCES}

Andrewes F W, Horder T J 1906 A study of the streptococci pathogenic for man. Lancet $1906 ; 2: 708-713,775-782,852-$ 855.

Bridge P D, Sneath P H A 1983 Numerical taxonomy of Streptococcus. Journal of General Microbiology 129:565597.

Carlsson J 1968 A numerical taxonomic study of human oral streptococci. Odontologisk Revy 19:137-160.

Colman G 1969 Transformation of viridans-like streptococci. Journal of General Microbiology 57:247-255.

Colman G, Williams R E O 1965 The cell walls of streptococci. Journal of General Microbiology 41:375-387.

Colman G, Williams R E O 1972 Taxonomy of some human viridans streptococci. In: Wannamaker $\mathbf{L}$ W, Matsen J M (eds) Streptococci and streptococcal diseases: Recognition, understanding and management. Academic Press, New York, pp 281-299.

Cowan S T 1974 Cowan and Steel's Manual for the identification of medical bacteria. 2nd edn. Cambridge University Press.

Coykendall A L, Munzenmaier A J 1978 Deoxyribonucleic acid base sequence studies on glucan-producing and glucannegative strains of Streptococcus mitior. International Journal of Systematic Bacteriology 28:511-515.

Coykendall A L, Specht P A 1975 DNA base sequence homologies among strains of Streptococcus sanguis. Journal of General Microbiology 91:92-98.

Cummins C S, Harris H 1956 The chemical composition of the cell wall in some Gram-positive bacteria and its possible value as a taxonomic character. Journal of General Microbiology 14:583-600.

Facklam R R 1977 Physiological differentiation of viridans streptococci. Journal of Clinical Microbiology 5:184-201.

Hamada S, Torii M, Tsuchitani Y, Kotani S 1980 Isolation and immunobiological classification of Streptococcus sanguis allow more variation in both these reactions than do other authors.

With the API-20/Strep system, we found that amongst strains resembling $S$. sanguis the correlation of arginine hydrolysis with high levels of wholecell rhamnose is almost perfect. We suggest therefore that $S$. sanguis may be distinguished from $S$. mitior in the clinical laboratory by the possession of arginine dihydrolase, and that strains of both $S$. sanguis and $S$. mitior may hydrolyse aesculin or produce dextran from sucrose or give both reactions. The API-20/Strep system is more reliable and sensitive than the conventional method for detecting arginine and aesculin hydrolysis.

We thank Dr I. S. Menzies for his help in setting up the method for whole-cell rhamnose estimation; and the colleagues mentioned in Materials and methods for the gift of streptococcal strains.

from human tooth surfaces. Journal of Clinical Microbiology 12:243-249.

Hardie J M, Bowden G H 1976 Physiological classification of oral viridans streptococci. Journal of Dental Research $\mathbf{5 5}$ Suppl 1A: Al66-A176.

Hare R 1935 The classification of haemolytic streptococci from the nose and throat of normal human beings by means of precipitin and biochemical tests. Journal of Pathology and Bacteriology 41:499-512.

Menzies I S, Mount J N, Wheeler M J 1978 Quantitative estimation of clinically important monosaccharides in plasma by rapid thin layer chromotography. Annals of Clinical Biochemistry 15:65-76.

Niven C F, Kiziuta Z, White J C 1946 Synthesis of a polysaccharide from sucrose by Streptococcus s.b.e. Journal of Bacterio$\log y$ 51:711-716.

Parker M T, Ball L C 1976 Streptococci and aerococci associated with systemic infection in man. Journal of Medical Microbiology 9:275-302.

Porterfield J S 1950 Classification of the streptococci of subacute bacterial endocarditis. Journal of General Microbiology 4:92-101.

Roberts R B, Krieger A G, Schiller N L, Gross K C 1979 Viridans streptococcal endocarditis: the role of various species, including pyridoxal-dependent streptococci. Reviews of Infectious Diseases. 1:955-966.

Roberts W S L, Stewart F S 1961 The sugar composition of streptococcal cell walls and its relation to haemagglutination pattern. Journal of General Microbiology 24:253-260.

Rosan B 1976 Relationship of the cell-wall composition of group H streptococci and Streptococcus sanguis to their serological properties. Infection and Immunity 13:1144-1153.

Rosan B, Appelbaum B 1979 An immunochemical study of Streptococcus sanguis and S. mitis. In: Parker M T (ed) Pathogenic streptococci. Reedbooks, Chertsey, pp 208-209. Schotmüller H 1903 Die Artunterscheidung der für den Mens- 
chen pathogenen Streptokokken durch Blutagar. Munchener Medizinische Wochenschrift 50:849-853, 909-912.

Slade H D, Slamp W C 1962 Cell-wall composition and the grouping antigens of streptococci. Journal of Bacteriology 84:345-351.

Waitkins S A, Ball L C, Fraser C A M 1980 A shortened scheme for the identification of indifferent streptococci. Journal of Clinical Pathology 33:47-52.
Washburn M R, White J C, Niven C F 1946 Streptococcus s.b.e.: immunological characteristics. Journal of Bacteriology 51:723-729.

White J C, Niven C F 1946 Streptococcus s.b.e.: a streptococcus associated with subacute bacterial endocarditis. Journal of Bacteriology 51:717-722. 